\title{
Risk and Protective Factors Associated with Kinship Care
}

\author{
Ainoa Mateos Inchaurrondo \\ M. Àngels Balsells Bailón \\ Crescencia Pastor Vicente \\ Eduard Vaquero Tió \\ Anna Mundet Bolós
}

\begin{abstract}
A. Mateos Inchaurrondo, Department of Methods and Diagnostic in Education, Group GRISIJ (Research group in social-educational interventions in infancy and adolescence), Faculty of Education, University of Barcelona, Passeig de la Vall d'Hebron 171, 08035 Barcelona, Spain, e-mail: amateos@ub.edu, URL: http://www.ub.edu/grisij/

M. A. Balsells Bailón and E. Vaquero Tió, Group GRISIJ, Faculty of Educational Science, University of Lleida, Lleida, Spain

C. Pastor Vicente and A. Mundet Bolo's Group GRISIJ, Faculty of Education, University of Barcelona, Barcelona, Spain
\end{abstract}

\begin{abstract}
This study aims to investigate the risk factors and protection factors associated with kinship foster care families (FF) who have overcome difficulties and been strengthened by their experience. Eighty-nine semi-structured interviews with kinship FF (foster carers) from four regions in Spain were conducted to identify the risk factors and protection factors that influence the stability of kinship foster care. Following analysis of the interview content, the results were separated into risk factors and protection factors related to the foster children (FC), the foster care families (FF) and the biological families (BF). The main risk factors for the FC were problems arising from mental and behavioral disorders and disabilities, problems related to foster care families' overprotection and to the negative perceptions of the $\mathrm{FC}$, and problems arising from the $\mathrm{BF}$ inadequate relationship with the foster carers and their infrequent contact and relationship with their children. The main protection factors related to the FC were identified as their levels of autonomy, maturity and adaptability; for the foster carers, these factors were positive relationships with the foster child as well as the formal and informal support received; and for the biological family, these factors included a good relationship and contact with the child. Finally, it discuss the implications that protective and risk factors have for foster child, foster family and biological family.
\end{abstract}

Keywords Foster care in kinship families, Risk factors and protection factors, Fostering children

\section{Introduction}

Kinship foster care has always existed in Spain, well before the proclamation of Law 21/1987 (BOE 1987), when it became a formally recognized form of child protection. This type of foster care is the most common in Spain (Del Valle et al. 2008) and in other countries (Berrick et al. 1994; Geen 2003). In 
Spain, $85 \%$ of fostering is through kinship care, and this percentage is much higher than that in other countries (Del Valle and Bravo 2003).

The controversial beginnings of kinship foster care contrast with the benefits reported on the progress of children who are fostered (Geen and Berrick 2002). Recent studies demonstrate more advantages (Montserrat 2012) than drawbacks in this type of fostering (Farmer et al. 2013). Among the advantages of this type of fostering are the continuity of personal, family and social history; fewer traumatic phases (CWLA 1994; Ehrle and Geen 2002); and fewer changes compared with fosterers outside of the family (Balsells et al. 2010). All these benefits-along with the willingness of the extended families to look after "their" children (grandchildren, nephews and nieces) to save both time and money for authorities-have contributed to the increase in kinship foster care to the extent that it is currently the first option considered when a child is separated from his/her nuclear family. However, the substantial increase in kinship foster care has not been accompanied by additional resources or studies of the issue.

All these benefits-along with the willingness of the extended families to look after "their" children (grandchildren, nephews and nieces) to save both time and money for authorities-have contributed to the increase in kinship foster care to the extent that it is currently the first option considered when a child is separated from his/her nuclear family. However, the substantial increase in kinship Foster care has not been accompanied by additional resources or studies of the issue (Amorós et al. 2008; Balsells et al. 2011; Bernedo and Fuentes 2010; Boada 2006; Del Valle et al. 2009; Geen and Berrick 2002; Hegar and Scannapieco 1999; Mateos et al. 2012). This lack of scientific research on kinship foster care makes it difficult to reach concrete conclusions regarding the strengths and weaknesses associated with this model (Mateos et al. 2012; Wilson et al. 2004). Previous studies clearly indicate that the difficulties that arise from this type of foster care relate to all three groups involved: foster children (FC), foster care families and biological families (BF). The risk factors associated with FC increase according to the amount of special attention that they require or the complexity of their behavior (Bass et al. 2004; Chipungu and Bent-Goodley 2004). Other risk factors are related to the age of foster carers, who are frequently elderly and have a low level of education, more health problems and lower incomes than outside fosterers (Amorós and Palacios 2004). The most important factor relating to the biological family is their attitude toward visits, which tend to be more frequent but more informal than in other types of foster care.

Such visits typically occur in the home of the foster care family and have little or no professional supervision. Evidence of complaints from extended families indicate that these visits are difficult to control (Del Valle et al. 2009; Jiménez and Palacios 2008; Montserrat 2007, 2012). It should be noted that the majority of the scientific literature focuses on risk and does not consider the complexities of kinship fostering or the benefits that this form of care affords FC. However, a protective approach can help families who are experiencing a variety of problems, difficulties or stressful situations (Walsh 2002). "Social work, with its strengths-based perspective that recognizes the person in the environment, is in a unique position to contribute to the knowledge in this area" (Corcoran and Nichols-Casebolt 2004). A new pattern is emerging in which researchers aim to see beyond the risk and risk factors associated with the different groups involved in foster care: the foster care family, the biological family and the foster child (Ellingsen et al. 2011; Harnett et al. 2012).

Given this protection-centered perspective and given the benefits of this form of child protection, we considered the need to more closely examine the factors that assure the stability of kinship foster care. Therefore, this article aims to answer the following questions: Which risk factors and protection factors are associated with kinship foster care? Which of these factors relate to the different groups involved in this type of foster care? Aims to answer these questions, the aim of the study was to identify the risk factors and protection factors related to FC, foster care families (FF) and BF. 
The qualitative study had both descriptive and explanatory purposes. The study is based on semistructured interviews that aim to obtain subjective views from foster care families in an attempt to understand their experiences, feelings and opinions expressed in their own words. Through these verbal accounts, this study determines the importance that these families attribute to their experiences.

\section{Participants}

Eighty-nine foster care families participated in the study, including $32.6 \%$ who were mono-parental and $67.4 \%$ who were married couples or partners. The ages of men in these foster care families ranged from 26 to 76, with an average age of 52.06 (DS 10.97), whereas the women's ages were between 28 and 74 , with an average of 51.67 (DS 11.41).

The socio-economic statuses of these families were low in $44.19 \%$ of cases, sufficient in $45.35 \%$ of cases and high in $10.47 \%$ of cases. Of the cases, $89 \%$ were permanent foster homes, while only $11 \%$ were temporary. The average age of the foster children was $12 ; 54.8 \%$ were girls, and $45.2 \%$ were boys.

\section{Instruments}

The research data were collected by conducting semistructured face-to-face interviews. As recommended by Webster and Mertova (2007), the structure of the questions was open to allow for reflection and to promote open conversation in which the families could tell their stories. This data collection technique allows for connections between events, facts and experiences over time through the words of the foster carers themselves.

The ad-hoc script of the interview consisted of 15 questions (Table 1) and focused on the foster carers' perception of 4 issues: the kinship foster's measure, the relationship with the biological family, the relationship with the foster child and their experiences as fosterers.

\section{Table 1 Questions asked in the interview}

\section{The kinship foster's measure}

1. What do you think of kinship family foster care?

2. Is there anything about the subject of foster care that worries you and you would like to talk about?

3. How would you rate your level of satisfaction with the foster care arrangement?

4. How would you explain to others what is "kinship foster care"?

Relationship with the biological family

5. How would you rate your level of satisfaction with the foster care arrangement?

6. Can you tell us about your relationship with other members of your family?

7. Do you talk much, do you show affection, do you help each other when there is a problem, do you see each other frequently, do you spend free time together...?

Relationship with the foster child

8. What do you find easiest in your relationship with the foster child and what is the most difficult?

9. What is a normal day like? 
10. Does the foster child participate at home, do what they should, or are they independent, without many limits?

11. What do you do when a problem occurs?

Experience as foster parents

12. When you have any kind of problem, personal or with the foster child, who do you turn to? (People, Professional staff, Institutions...)

13. Why do you normally ask for help?

14. How do you feel when you have to do this?

15. If you don't normally do this, what are the disadvantages of not asking for help whenever you need it?

\section{Procedure}

The participants were contacted through child protection welfare services in four regions of Spain. The research team and the welfare staff selected the families to participate in the study based on their availability, their motivation and the needs of each region, as well as the personal, family, parental and social characteristics of the families.

Data were collected through in-depth interviews with the foster care families. When possible, the couples in each family were interviewed together ( $49 \%$ of the interviews were conducted with both foster parents, whereas $51 \%$ of the interviewees included only 1 member of the foster care family), and the duration of the interviews was between 60 and $90 \mathrm{~min}$. These interviews were conducted by one of our researchers with experience in qualitative data collection techniques following the recommendations of Taylor and Bogdan (1994). All interviews were recorded and subsequently transcribed for analysis following ethical guidelines of informed consent and confidentiality.

\section{Data Analysis}

The 89 transcriptions of interviews with foster care families required complex content analysis. A category system was created, with an initial analysis of 5 interviews by five judges who were researchers on the team.

The final categories were the following: a) Factors related to the foster child: a.1. Attitude toward the protection measure; a.2. Social support; a.3. Personality and behavior; a.4. Health; a.5. School; and a.6. Feelings and emotions. b) Factors related to the foster care family: b.1. Attitude toward the protection method; b.2. Social support; b.3. Parental role; b.4. Family environment; and b.5. Social and family characteristics. c) Factors related to the biological family: c.1 Attitude toward the protection method; c.2. Social support; c.3. Relationship with children; c.4. Personal characteristics; and c.5. Social and family characteristics.

Once the category system was established, a double system of judges was established for each of the interviews: each pair of judges performed an individual reading, analysis and codification; a consensus was then reached in the case of any discrepancy between the judges; and, finally, qualitative data codification was conducted using the professional software Atlas-Ti-V6.2 Qualitative data analysis (QDA). 
Therefore, the first phase of analysis was textual: paragraphs, fragments and significant quotations were selected from the interview transcriptions. The second phase was conceptual and involved a higher level of analysis in which codes and categories were created and subsequently used to establish relationships among the data. These two phases were continually interrelated throughout the analysis process.

This approach allowed for modifications in the degree of importance attributed to a quotation or paragraph at a certain point in the analysis process, and it facilitated a closer examination of the level of conceptualization.

Given these considerations, a list of protection and risk factors was created to incorporate two perspectives:

1. In the interviews, the foster care families discussed issues concerning the foster children, the biological family and their own experience as foster carers. They discussed the risk and protection factors from their own perspective.

2. The researchers were able to identify protection or risk factors even when they were not explicitly mentioned by the foster care families; the researchers made deductions based on the interviewees' words, which is legitimate according to the scientific literature.

\section{Findings}

The results confirm the variety of risk and protection factors associated with kinship foster care families as well as the complexity and constant interactions of these factors deriving from all the groups involved in kinship care. The balance between these factors is important in understanding the progress and evolution of this type of foster care.

The factors that were identified relate to the nature of the different groups as well as the contextual and relational factors that influence the most stable and successful arrangements among foster children, foster care families and BF.

The results were classified according to the data analysis category system. However, these factors can evolve and interact because of the changing nature of family relationships. Thus, the factors presented are not static or invariable but can facilitate or impede the process of foster care and the relationships established between foster carers and foster children.

\section{Foster Child}

The risk factors linked to foster children are personal characteristics, behavior and attitude (Table 2). The main risk factors are related to personality and behavior (aggressive character and poor behavior), anti-social behavior, the failure to accept rules and limits, poor school performance (backward progress, school failure, and school absenteeism), difficulties resulting from health problems or disabilities, and the failure to accept the foster care situation.

Table 2. Risk and protection factors related to the foster child

\begin{tabular}{|l|l|l|l|l|l|l|l|l|}
\hline & a1 & a2 & a3 & a4 & a5 & a6 & $\mathrm{fi}_{i}$ \\
\hline Risk factors & X & & & & & & 4 \\
\hline Not accepting the foster family & & & & & & \\
\hline
\end{tabular}




\begin{tabular}{|c|c|c|c|c|c|c|c|}
\hline Lack of information about foster care & $\mathrm{X}$ & & & & & & 3 \\
\hline Social isolation & & $\mathrm{X}$ & & & & & 4 \\
\hline Aggressive character, bad behaviour & & & $\mathrm{X}$ & & & & 12 \\
\hline Not accepting limits and norms. External control locus. & & & $\mathrm{X}$ & & & & 7 \\
\hline Closed character. & & & $\mathrm{X}$ & & & & 5 \\
\hline Antisocial behaviour (robberies, vandalism, etc.) & & & $\mathrm{X}$ & & & & 4 \\
\hline Risk behaviour (using drugs, alcohol, etc.) & & & $\mathrm{X}$ & & & & 2 \\
\hline $\begin{array}{l}\text { Problems derived from mental and behavioural disorders, } \\
\text { disabilities and slow development. }\end{array}$ & & & & $\mathrm{x}$ & & & 11 \\
\hline Difficulties derived from health problems. & & & & $\mathrm{x}$ & & & 4 \\
\hline Learning disabilities (school absenteeism, school failure, etc.) & & & & & $\mathrm{X}$ & & 15 \\
\hline Rejection of biological or foster family & & & & & & $\mathrm{X}$ & 5 \\
\hline Emotional needs & & & & & & $\mathrm{X}$ & 3 \\
\hline \multicolumn{8}{|l|}{ Protection factors } \\
\hline Acceptance of foster care situation & $\mathrm{X}$ & & & & & & 4 \\
\hline A good relationship \& contact with brothers and sisters & & $\mathrm{X}$ & & & & & 8 \\
\hline School support systems & & $\mathrm{X}$ & & & & & 2 \\
\hline Level of autonomy, maturity and adaptability & & & $\mathrm{X}$ & & & & 10 \\
\hline Friendly character (open, extrovert, cheerful, communicative) & & & $\mathrm{X}$ & & & & 10 \\
\hline Having social skills & & & $\mathrm{X}$ & & & & 10 \\
\hline Positive behaviour & & & $\mathrm{x}$ & & & & 8 \\
\hline High level of intelligence & & & $\mathrm{X}$ & & & & 4 \\
\hline Respect for limits and norms & & & $\mathrm{X}$ & & & & 4 \\
\hline Able to recognize his/her own faults & & & $\mathrm{X}$ & & & & 2 \\
\hline Ability to listen & & & $\mathrm{X}$ & & & & 2 \\
\hline Postive references & & & $\mathrm{X}$ & & & & 2 \\
\hline Sport activities & & & & $\mathrm{X}$ & & & 2 \\
\hline Looking after health problems & & & & $\mathrm{X}$ & & & 2 \\
\hline A healthy way of life & & & & $\mathrm{X}$ & & & 2 \\
\hline Good school performance & & & & & $\mathrm{X}$ & & 5 \\
\hline
\end{tabular}




\begin{tabular}{|l|l|l|l|l|l|l|l|}
\hline Affectionate & & & & & & X & 9 \\
\hline
\end{tabular}

a.1. Attitude towards foster care measure; a.2.Social support; a.3. Personality and behaviour; a4. Health; a.5. School; a.6. Feelings and emotions; fi: frequency 
"At first, our relationship was very bad. He hit me, insulted me and psychologically mistreated me as a mother using words not fit for a three-year-old. So, I asked his mother why she didn't spend a day with her son, even five minutes...After seven years, I couldn't understand why they wanted the child to see his mother again, when the mother hadn't bothered with him at all." -Foster family.

The main protection factos are also related to the personality and behavior (autonomy, maturity, intelligence, and acceptance of rules and limits) and social skills of foster children. Other important factors include social support from family members, school and peers as well as good academic performance.

"He's fine at school because in addition to normal classes, he's got a support teacher. He's learning to do his homework in his bedroom. He says, "Grandma, today this happened with the gym teacher...because I beat him in basketball or handball.' He tells me everything that happens at school." -Foster family

\section{Foster Care Family}

The factors linked to the foster care family as the nucleus of a child's development and protection also varied (Table 3). Difficulties arising from health problems or precarious economic situations were prominent among the risk factors, in addition to an overprotective attitude toward the foster child, a negative view of the biological family or the foster child, and even a lack of motivation to continue with the foster care. Risk factors related to family and parental development, such as domestic disorganization, a lack of rules and limits, and marital problems, were also identified.

Table 3. Risk and protection factors related to the foster family

\begin{tabular}{|c|c|c|c|c|c|c|}
\hline & b1 & b2 & b3 & b4 & b5 & $\mathrm{fi}_{\mathrm{i}}$ \\
\hline \multicolumn{7}{|l|}{ Risk factors } \\
\hline Negative idea of the biological family & $\mathrm{x}$ & & & & & 9 \\
\hline Erroneous idea of the role of the foster parents & $\mathrm{X}$ & & & & & 4 \\
\hline Fear of the sudden end to foster care & $\mathrm{X}$ & & & & & 4 \\
\hline Hiding the family reality from the foster child & $\mathrm{X}$ & & & & & 3 \\
\hline Social isolation & & $\mathrm{X}$ & & & & 2 \\
\hline Need for psychological \& social support & & $\mathrm{X}$ & & & & 2 \\
\hline Overprotection of the foster child & & & $\mathrm{X}$ & & & 5 \\
\hline Negative idea of the foster child & & & $\mathrm{X}$ & & & 4 \\
\hline Lack of limits, norms, etc. & & & $\mathrm{X}$ & & & 2 \\
\hline Domestic disorganization & & & & $\mathrm{X}$ & & 3 \\
\hline Matrimonial problems & & & & $\mathrm{X}$ & & 3 \\
\hline Lack of communication between family members & & & & $\mathrm{X}$ & & 1 \\
\hline
\end{tabular}




\begin{tabular}{|c|c|c|c|c|c|c|}
\hline Difficulties derived from health problems & & & & & $\mathrm{X}$ & 8 \\
\hline Economic problems and job insecurity & & & & & $\mathrm{X}$ & 8 \\
\hline Generational differences with the foster child & & & & & $\mathrm{X}$ & 4 \\
\hline Death of one of the foster parents & & & & & $\mathrm{X}$ & 3 \\
\hline Low educational level of the Foster parents & & & & & $\mathrm{X}$ & 2 \\
\hline \multicolumn{7}{|l|}{ Protection factors } \\
\hline Positive attitude, predisposition and motivation towards Foster care & $\mathrm{X}$ & & & & & 24 \\
\hline A good relationship with the biological family & $\mathrm{X}$ & & & & & 10 \\
\hline Identifying their role as foster parents & $\mathrm{X}$ & & & & & 7 \\
\hline Respect for the origins of the foster child and his/her parents & $\mathrm{X}$ & & & & & 7 \\
\hline Realizing their limits as foster parent & $\mathrm{X}$ & & & & & 6 \\
\hline Show willing and motivation towards learning & & $\mathrm{X}$ & & & & 17 \\
\hline Psychological support \& attention & & $\mathrm{X}$ & & & & 10 \\
\hline Family support & & $\mathrm{X}$ & & & & 8 \\
\hline School support \& help. Family - school collaboration & & $\mathrm{X}$ & & & & 7 \\
\hline Support from the extensive family & & $\mathrm{X}$ & & & & 5 \\
\hline Satisfaction appreciation for the formal support received & & $\mathrm{X}$ & & & & 3 \\
\hline Support from social services & & $\mathrm{X}$ & & & & 3 \\
\hline Looking for resources and solutions to the foster child's problems & & $\mathrm{X}$ & & & & 3 \\
\hline Good relationship with neighbours & & $\mathrm{X}$ & & & & 2 \\
\hline Economic help & & $\mathrm{X}$ & & & & 2 \\
\hline $\begin{array}{l}\text { A good relationship between foster parents and foster child } \\
\text { (affection, attachment, support, etc.) }\end{array}$ & & & $\mathrm{x}$ & & & 29 \\
\hline Good prospects for the future and progress & & & $\mathrm{X}$ & & & 2 \\
\hline $\begin{array}{l}\text { Trust \& ability between the foster parents and foster child to talk } \\
\text { about anything }\end{array}$ & & & $\mathrm{X}$ & & & 2 \\
\hline Family organization (norms, standards, habits, etc.) & & & & $\mathrm{X}$ & & 3 \\
\hline Communication and good dialogue & & & & $\mathrm{X}$ & & 3 \\
\hline
\end{tabular}

b.1.Attitude towards the protection measure; b.2.Social support; b.3. Parental Role; b.4. Family atmosphere; b.5. Social and family characteristics; fi: frequency 
"We have allowed him everything, so now he doesn't accept the rules that we have set for him. By protecting him too much, we've spoiled him... He's difficult, and he doesn't understand when you say no because we've always said yes."-Foster family.

A good relationship with the biological family and with the foster child can improve protection factors. When foster carers maintain a positive attitude and motivation with respect to kinship care or are willing to receive information and other support (both formal and informal, e.g., extended family), these factors can contribute to the stability and success of kinship care.

"I'm very happy to have them, in my own way; it's better than having them be in a foster home, being looked after by other people. If I need any help, I ask for it from my neighbor or the people who work in social services." -Foster family

\section{Biological Family}

With regard to the risk factors linked to BFs, the limited or non-existent relationship with foster children and other family members (e.g., brothers and sisters, step-brothers and stepsisters, uncles and aunts, grandparents) can be identified as a risk factor. A lack of collaboration between a biological family and a foster care family can be a risk factor that affects the stability of fostering, especially if there is a negative relationship between the families. Other risk factors related to biological family members arise when biological family members exhibit antisocial behavior, such as drug or alcohol abuse; when one of the parents is unknown or has disappeared; when one's brothers or sisters are in a foster family; or when one parent is receiving some form of treatment for mental or behavioral disorders. The main protective factors are a good relationship between the foster child and the foster care family and collaboration between both families to attend to the needs of the child. Agreements regarding visits can also be considered a protective factor that contributes to supporting and stabilizing foster care (Table 4).

Table 4 Risk and protection factors related to the biological family

\begin{tabular}{|c|c|c|c|c|c|c|}
\hline & c1 & c2 & c3 & c4 & c5 & $f_{i}$ \\
\hline \multicolumn{7}{|l|}{ Risk factors } \\
\hline $\begin{array}{l}\text { Bad relationship with the foster family (legal complaints, accusations, } \\
\text { etc.) }\end{array}$ & $\mathrm{x}$ & & & & & 15 \\
\hline Lack of motivation to continue with the foster care measure & $X$ & & & & & 9 \\
\hline Lack of collaboration with the foster family & $\mathrm{X}$ & & & & & 8 \\
\hline Problems with \& lack of agreements about visits & $X$ & & & & & 5 \\
\hline $\begin{array}{l}\text { Not respecting the established agreements made with the Foster } \\
\text { family. }\end{array}$ & $\mathrm{X}$ & & & & & 2 \\
\hline Giving false hope to the Foster child about his/her return & $\mathrm{X}$ & & & & & 2 \\
\hline Little or no relationship and contact with close family & & $\mathrm{X}$ & & & & 12 \\
\hline
\end{tabular}




\begin{tabular}{|c|c|c|c|c|c|}
\hline Limited relationship, Little contact or communication with child & & $\mathrm{X}$ & & & 15 \\
\hline Giving contradictory information to the child & & $\mathrm{X}$ & & & 3 \\
\hline Negative feelings towards the foster parents & & $\mathrm{X}$ & & & 2 \\
\hline Use of drugs and other substances & & & $\mathrm{X}$ & & 10 \\
\hline Antisocial behaviour & & & $\mathrm{X}$ & & 2 \\
\hline Father/ mother of foster child unknown/ disappeared & & & & $\mathrm{X}$ & 4 \\
\hline Brothers \& sisters under social protection measures & & & & $\mathrm{X}$ & 3 \\
\hline \multicolumn{6}{|l|}{ Protection factors } \\
\hline Good relationship with Foster family & $\mathrm{X}$ & & & & 15 \\
\hline Acceptance and consent towards foster care & $\mathrm{X}$ & & & & 6 \\
\hline Collaboration with the foster family & $\mathrm{X}$ & & & & 4 \\
\hline Non-problematic visits & $\mathrm{x}$ & & & & 2 \\
\hline Good relationship \& contact with the foster child & & $\mathrm{X}$ & & & 19 \\
\hline Attending reinsertion, detoxification programmes etc. & & & & $\mathrm{X}$ & 2 \\
\hline
\end{tabular}

c.1. Attitude towards the foster care measure; c.2.Social support; c.3.Relationship with their children; c.4. Personal characteristics; c.5. Social and family characteristics; fi :frequency

"The first thing you find about these children is that they need a lot of affection. They need a lot of patience and attention. It's not so much about how much you give them but how you look after them. We have been lucky in that we get on well with her mother; we talk about things. She sometimes sees her mother and comes home happy. [Her mother] had drug problems, and getting out of that situation requires great sacrifice and effort. But if you're a generous, loving person, you give them a lot of affection and love." -Foster family.

The risk factors and protective factors identified indicate that opinions and attitudes toward kinship care measure are apparent in the foster child, the foster care family and the biological family.

However, the decisive element that determines the success and continuity of kinship foster care is the balance between these factors and the contexts in which they develop. Therefore, these results should be considered in view of the environment, as the child is part of the social and family system in which he/she is raised. The different contexts of development of the foster child, the foster care family and the biological family have a significant role in the success of foster care. Among these contexts, the dynamic relationship between all factors is the most important element in determining the ability of each foster care family to face the challenges associated with this form of care. 


\section{Discussion}

\section{Foster Child}

The factors related to foster children that we identified in our research are connected to behavior and personality, school issues, health and the emotional and personal sphere. The main risk factors related to behavior and personality correspond to aggressiveness, disrespect for limits and rules, antisocial behavior, a closed character and social isolation, among others. These results confirm the findings of Del Valle, López, et al. (2009) stating that these factors, along with school- and health-related problems, are the most frequent issues occurring among foster children.

Likewise, the protection factors include the foster child having an independent character, being positive and friendly, and having social skills that act as protective factors.

The second most significant group of factors for foster children is related to school. Problems related to backward progress, absenteeism, and school failure in general were identified as risk factors. This finding coincides with the results reported by Monteoliva and Martínez (2007), who found significant differences in academic achievement between children living with their BFs and those living in residential care. Having a familiar household affects the academic progress of children. The results of this research are also consistent with those of other studies that identify school problems, progress and behavior as risk factors (Del Valle et al. 2008; Palacios 2007). Using similar reasoning, good academic achievement can be considered a protection factor.

Foster children also have issues related to health problems. Some of the risk factors that arise from mental and behavioral disorders and disabilities benefit little from social-educational intervention. Backhouse and Grahan (2012) emphasized that physical and emotional health problems - which the foster children indicated affected them the most-are often a result of abuse or neglect by their biological parents. Thus, protective factors in this area are related to living a healthy life in general, such as by playing sports and maintaining physical health.

This study also provides information on how the personal and emotional spheres are factors that influence foster care. The results of this study are strengthened by the findings of Ellingsen et al. (2011), Keller et al. (2001) and Shore et al. (2002), who reported that highly positive evaluations of foster carers are inherent factors in this type of foster care. In other words, paying attention and applying an intervention that accounts for the emotional aspects experienced by all groups involved in the process can positively influence the well-being of all involved and promote progress. A foster child's rejection of his/her biological family or foster care family is therefore viewed as a risk factor, in addition to the lack of emotional care that is necessary for healthy and satisfactory development of foster children. The most important protection factor for foster children is the presence of affectionate adult foster carers who allow them to express their needs, which are in turn more likely to be met.

\section{Foster Family}

The principal factors identified in our study related to foster care families are social support, the position and attitude that a family adopts toward kinship foster care, and the parental role. With respect to social support, two main risk factors have been identified. One of these factors is related to social isolation, which occurs in families without any type of formal or informal 
social support; these families have greater risks in the process of foster care. This lack of support for their efforts as foster carers has been affirmed in national and international studies (Amorós and Palacios 2004; Jiménez and Palacios 2008; Mateos et al. 2012; Ponciano 2010).

From this factor, another risk factor stems: the need for psychological and legal assistance, which is a specific type of social support. The risk factors related to social support relate to the presence of social support, whether formal (e.g., psychological support and attention, support from school, social services, economic assistance) or informal (e.g., support from the nuclear family and extended family, a good relationship with neighbors), and the appreciation of this support. It is crucial not only to have this support but also to appreciate and identify that this support serves as a factor of protection. This importance is related to the data provided by Baeza (2000), who considers family cohesion, adaptability to intrinsic changes in the family (e.g., roles, balance of power, norms) and family communication as key characteristics of families who face difficulties in a positive manner. Jiménez and Zavala (2011) also noted that psychological support is one of the types of support that participating families value the most. Moreover, Harnett et al. (2012) stated that practical and emotional support is valued highly by foster grandparents. It is evident that family support is one of the important types of informal support in this type of family care and should therefore be strengthened because this support is generally not very extensive. The studies of Rodrigo et al. (2007) and Rodrigo (2007) also recognized informal support provided by friends, neighbors, volunteers, and others as a protective factor.

Second, the attitude of foster care families toward protection is also identified as an important factor in the success of foster care. It is evident that a negative attitude toward the biological family, a misguided view of their role as foster care families and the fear of a sudden end to this care are the most important risk factors in this area. The main protection factors for foster care families are related to having a good relationship with BFs and a good understanding of their role as foster care families. These aspects are based on a positive attitude, a willingness and motivation to make the foster care work, recognition for their efforts and recognition of their limits as foster carers while simultaneously respecting the origins of the foster child and the biological family (Amorós and Palacios 2004).

The third factor that influences foster care families is related to their attitude toward foster care. These risk factors relate to the type of parental role, the understanding of overprotection, the negative attitude of the foster child and a lack of limits and norms. Meanwhile, the protection factor identified that most concerns foster care families is a good relationship between foster carers and foster children (e.g., affection, attachment, support). Mutual trust, the ability to communicate openly and positive expectations for the future are also important.

Characteristics of families and can be helped little by social-educational involvement because they pertain to health problems and job insecurity. Such problems could arise because the profile of some foster care families is similar to that of the biological family in terms of unfavorable economic situations. 
The factors related to biological families largely depend on the type of relationship between the groups affected by foster care, particularly their attitudes toward foster care and their relationships with their children.

With regard to attitude, the main risk factor concerning biological families is an inadequate relationship with foster families (e.g., legal complaints, accusations), followed by a lack of motivation, a lack of collaboration in following the process of foster care, the creation of problems and noncompliance with visiting agreements established with the foster care family. All these risk factors are reflected in foster children's false hopes of return, which also becomes a risk factor. The protection factors include having a positive relationship with the foster care family as a result of collaboration, complying with visit arrangements, and satisfactorily accepting and consenting to the terms of foster care. Balsells et al. (2011) emphasized the importance of these visits and the relationship that children have with their biological families as a protective element.

Furthermore, Amorós et al. (2008) described the relationship between the biological family and the foster child as fundamental to creating a positive atmosphere in the foster care situation to ensure that the foster child can accept the situation in a positive way. This finding emphasizes a current but often forgotten need in this process: the general need to involve the biological family in the foster care arrangement.

A second aspect of the factors related to biological families is the nature of their relationship with their children. The risk factors identified here included a lack of contact or communication with their children; the provision of contradictory information; and, in the emotional sphere, the display of negative feelings toward the children or toward the foster care family. On the contrary, maintaining a positive relationship and contact with children is a protection factor (Amorós and Palacios 2004).

\section{Conclusions}

The study has allowed us to examine risk and protection factors among the groups of people involved in kinship foster care and to understand how these different factors influence the stability of this type of care.

Future research should examine the characteristics of professional involvement. According to Amorós and Palacios (2004), to complete the pyramid of foster care, a new vertex of professional involvement is needed. Excerpts from the experiences recounted by the foster care families highlight the importance of the training of welfare staff, the quality of assistance received and the need for monitoring and training. Thus, we must continue research in this area by considering these four groups that constitute the pyramid of foster care (Fig. 1). 


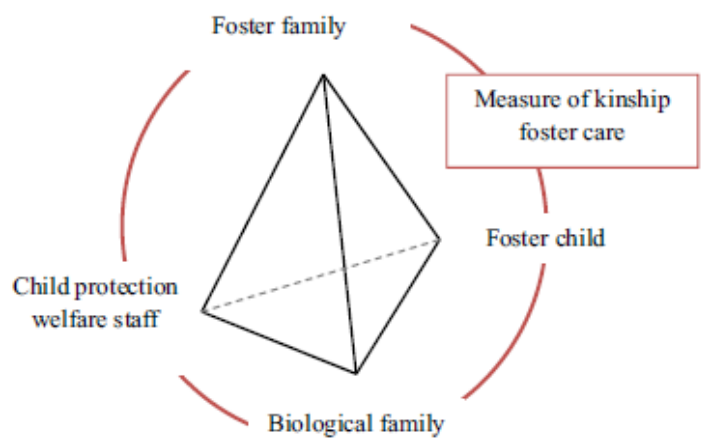

Fig. 1 Protagonist groups of kinship foster care

However, some of the protective factors found in our study could be considered factors of family resilience, such as satisfaction in the parental role of foster carers and positive expectations for foster children. This perspective is especially relevant because European social policies are currently favoring an increase in this type of foster care.

We need to observe the mechanisms that foment this resilience in such families in the context of the doubly difficult challenges associated with kinship foster care:

1. The foster care itself, a situation that is frequently accompanied by feelings of failure and pain in relation to the biological family

2. The psychosocial context of these families, whose economic, work and social situations are typically of a medium to low profile

Future studies should provide answers to the following questions: What aspects constitute the resilience of these extended families? Which elements have helped them to face the problems that they have encountered? How can we maximize these elements to make the extended family the primary source of support for desperate young parents?

\section{Acknowledgments}

This study has been developed by the research group GRISIJ (research group in socialeducational child intervention) and financed by the Spanish Ministry of Science and Technology (EDU2008-00340/EDUC), the Department of Innovation, Universities and Business of Government of Catalonia (2009SGR1392), the University of Barcelona and the University of Lleida.

\section{References}

Amorós, P., Fuentes, N., Pastor, C., Lozano, P., Comellas, M. J., \& Molina, M. C. (2008). Les besoins de soutien socio-éducatif des familles dans le cadre du placement dans un milieu familial élargi. La Revue Internationale de L'éducation Familiale, 23, 143-164.

Amorós, P., \& Palacios, J. (2004). Acogimiento familiar. Madrid: Alianza Editorial.

Backhouse, J., \& Grahan, A. (2012). Grandparents raising grandchildrens negotiatins the complexities of role identity conflict. Child and Family Social Work, 17, 306-315. 
Baeza, S. (2000). El Rol de la Familia en la Educación de los hijos. Retrieved from Facultad de Psicología y Psicopedagogía de la USAL. http://psico.usal.edu.ar/psico/rol-familia-educacionhijos.

Balsells, M. A., Amorós, P., Fuentes-Peláez, N., \& Mateos, A. (2011). Needs analysis for a parental guidance program for biological family: Spain's current situation. Revista de Cercetare si Interventie Sociala, 34, 21-37.

Balsells, M. A., Fuentes-Peláez, N., Mateo, M., Mateos, A., \& Violant, V. (2010). Innovación socioeducativa para el apoyo de adolescentes en situación de acogimiento familiar. Educar, 45, 133-148.

Bass, S., Shields, M. K., \& Behrman, R. E. (2004). Children, families and foster care: Analysis and recomendations. Children, Families, and Foster Care, 14, 4-29.

Bernedo, I., \& Fuentes, M. J. (2010). Necesidades de apoyo y satisfacción en los acogimientos con familia extensa. Anales de Psicología, 26, 95-103.

Berrick, J. D., Barth, R. P., \& Needell, B. (1994). A comparison of kinship foster homes and foster family homes: Implications for kinship foster care as family preservation. Children and Youth Services Review, 16, 33-63. doi:10.1016/0190-7409(94)90015-9.

Boada, C. (2006). Acogimiento en familia extensa: Un estudio desde la perspectiva de los acogedores, de los niños y niñas acogidos y de los profesionaeles que intervienen. Intervención Psicosocial, 15, 203-221.

BOE. (1987) LEY 21/1987, de 11 de noviembre, por la que se modifican determinados artículos del Código Civil y de la Ley de Enjuiciamiento Civil en materia de adopción. Boletín Oficial del Estado, núm. 275/1987, de 17 de noviembre de 1987. Spain: Boletín Oficial del Estado.

Chipungu, S. S., \& Bent-Goodley, T. B. (2004). Meeting the challenges of contemporary foster care. The Future of Children, 14, 74-93.

Corcoran, J., \& Nichols-Casebolt, A. (2004). Risk and resilience ecological framework for assessment and goal formulation. Child and Adolescent Social Work Journal, 21, 211-235. doi:10.1023/B:CASW.0000028453.79719.65.

CWLA. (1994). Kinship care: A natural bridge. Washington: Child Welfare League of America.

Del Valle, J. F., \& Bravo, A. (2003). Situación actual del acogimiento de menores en España. Oviedo: Universidad de Oviedo.

Del Valle, J. F., Bravo, A., \& López, M. (2009). El acogimiento familiar en España: Implantación y retos actuales. Papeles del Psicólogo, 30, 33-41. Retrieved from http://www.papelesdelpsicologo.es/pdf/1654.pdf.

Del Valle, J. F., López, M., Montserrat, C., \& Bravo, A. (2008). El acogimiento familiar en España. Una evaluación de resultados. Ministerio de Trabajo y Asuntos Sociales (pp. 1-242).

Del Valle, J. F., López, M., Montserrat, C., \& Bravo, A. (2009b). Twenty years of foster care in Spain: Profiles, patterns and outcomes. Children and Youth Services Review, 31, 847-853. doi:10.1016/j.childyouth.2009.03.007.

Ehrle, J., \& Geen, R. (2002). Kin and non-kin foster care. Findings from a national survey. Children and Youth Services Review, 24, 15-35. doi:10.1016/S0190-7409(01)00166-9. 
Ellingsen, I. T., Shemmings, D., \& Størksen, I. (2011). The concept of 'Family' among Norwegian adolescents in long-term foster care.

Child and Adolescence Social Work Journal, 28, 301-318. doi:10.1007/s10560-011-0234-0.

Farmer, E., Selwyn, J., \& Meakings, S. (2013). 'Other children say you're not normal because you don't live with your parents'. Children's views of living with informal kinship carers: Social networks, stigma and attachment to carers. Child and Family Social Work, 18, 25-34. doi:10.1111/cfs.12030.

Geen, R. (2003). Foster children placed with relatives often receive less government help. New

Federalism: Issues and Options for State, A-59, 1-6. Retrieved from http://www.urban.org/publications/310774.html.

Geen, R., \& Berrick, J. D. (2002). Kinship care: An evolving service delivery option. Children and Youth Services Review, 24, 1-14. doi:10.1016/S0190-7409(01)00165-7.

Harnett, P. H., Dawe, S., \& Russell, M. (2012). An investigation of the needs of grandparents who are raising grandchildren. Child and Family Social Work, 19, 411-420. doi:10.1111/cfs.12036.

Hegar, R., \& Scannapieco, M. (1999). Kinship foster care: Policy, practice and research. Oxford: Oxford University Press. Jiménez, J., \& Palacios, P. (2008). El acogimiento familiar en Andalucía: Procesos familiares, perfiles personales. Granada: Junta de Andalucía. Consejería para la Igualdad $y$ Bienestar Social. Retrieved from http://www.observatoriodelainfancia.es/oia/esp/descargar. aspx?id=2191\&tipo=documento.

Jiménez, J. M., \& Zavala, M. I. (2011). Estrés parental y apoyo social en familias extensas acogedoras chilenas y españolas. Infancia y Aprendizaje, 34, 495-506.

Keller, T., Wetherbee, K., Le Prohn, N., Payne, V., Sim, K., \& Lamont, E. (2001). Competencies and problem behaviors of children in family foster care: Variation by kinship placement status and race. Children and Youth Services Review, 23, 915-940. doi:10.1016/S01907409(01)00175-X.

Mateos, A., Balsells, M.A., Molina, M. C.,\& Fuentes-Peláez, N. (2012). The perception adolescents in kinship foster care have of their own needs. Revista de Cercetare si Interventie Sociala, 38, 25-41.

Monteoliva, A., \& Martínez, J. M. (2007). Diferencias en los logros socioeducativos y laborales alcanzados por jo'venes que han vivido en dos entornos diferentes: Hogar familiar o residencia escolar. Revista Mexicana de Psicología, 24, 139-148.

Montserrat, C. (2007). Kinship foster care: A study from the perspective of the caregivers, the children and the child welfare workers. Psychology in Spain, 11, 42-52.

Montserrat, C. (2012). Kinship care in Spain: Messages from research. Child and Family Social Work, 19, 367-376. doi:10.1111/cfs.12028.

Palacios, J. (2007). Después de la adopción: Necesidades y niveles de apoyo. Anuario de Psicología, 38, 181-198. 
Ponciano, L. (2010). Attachment in foster care: The role of maternal sensitivity, adoption, and foster mother experience. Child and Adolescent Social Work Journal, 27, 97-114. doi:10.1007/s10560-010-0192-y.

Rodrigo, M. J. (2007). La resiliencia parental en situaciones de riesgo psicosocial: Implicaciones para el trabajo profesional. La Laguna: Facultad de Psicologia. Universidad de la Laguna.

Rodrigo, M. J., Máiquez, M. L., Martín, J. C., \& Rodríguez, G. (2007). Informal and formal supports and maternal child-rearing practices in at-risk and non at-risk psychosocial contexts.Children and Youth Services Review, 29, 329-347. doi:10.1016/j.childyouth.2006.03.010.

Shore, N., Sim, K., Le Prohn, N., \& Keller, T. (2002). Foster parent and teacher assessments of youth in kinship and non-kinship foster care placements: Are behaviors perceived differently across settings? Children and Youth Services Review, 24, 109-134. doi:10.1016/S01907409(01)00170-0.

Taylor, S. J., \& Bogdan, R. (1994). Introducción a los métodos cualitativos de investigación. Barcelona: Paidós.

Walsh, F. (2002). A family framework: Innovative practice applications. Family Relations, 51, 130-137. doi:10.1111/j.1741-3729.2002.00130.x.

Webster, L., \& Mertova, P. (2007). Using narrative inquiry as a research method: An introduction to using critical event narrative analysis in research on learning and teaching. NewYork: Routledge

Taylor \& Francis Group. Wilson, K., Sinclair, L., Taylor, C., Pithouse, A., \& Sellick, C. (2004). Fostering success: An exploration of the research literature on foster care. London: Social Care Institute for Excellence. 